\title{
Ganoderma spp. Basidioma Variation from Infected Oil Palm on Smallholder Peatland Plantation in Kampar Regency, Riau, Indonesia
}

\author{
Rachmad Saputra ${ }^{1, *}$ Anthony Hamzah ${ }^{1}$ Fifi Puspita ${ }^{1}$ Besri Nasrul ${ }^{1}$ Irfandri $^{1}$ \\ ${ }^{1}$ Agrotechnology Department, Agriculture Faculty,Universitas Riau, Pekanbaru, 28293, Riau, Indonesia \\ "Corresponding author. rachmadsaputra@lecturer.unri.ac.id
}

\begin{abstract}
A total of 15 types of Ganoderma diversity in the world have been identified. In Indonesia, information related to the variety of Ganoderma has not been widely reported. Ganoderma is the main cause of stem rot disease of oil palm plants, which has been reported to attack at various stages of plant growth. Information regarding the genetic diversity of Ganoderma needs to be known, considering that each pathogen has specificity in causing disease. This information is necessary to determine how the mechanism of infection, spread, and the response of plants to the presence of each type of Ganoderma in the physiological processes of oil palm plants. This research was conducted using survey methods in smallholder oil palm plantations in Kampar Regency and the Plant Disease Laboratory, Faculty of Agriculture, Riau University. The basidioma of Ganoderma spp. taken from the trunk of the infected oil palm tree. Basidioma of Ganoderma spp. then characterized based on its color. The data from these observations were then analyzed descriptively and presented in the form of tables and pictures. Field observations indicate that the presence of Ganoderma basidioma at the oil palm trunk is closely related to visual plant symptoms. Based on symptom observation results showed $62.07 \%$ severe symptoms, $10.34 \%$ dead plants, $20 \%$ had moderate symptoms and only $6.90 \%$ had mild symptoms. The plant condition in Deli Makmur Village shows severe symptoms with a severity index reaching 75\%. There were 6 groups of Ganoderma based on the characteristic color variations of the basidioma found in the sample locations. The Gano-1 group is the group with the highest incidence found in the field. This study also found $48 \%$ of infections of more than one Ganoderma group in one oil palm plant. Further testing is needed to determine the diversity of this Ganoderma species based on its genetic characteristics.
\end{abstract}

\section{Keywords: basidioma, diversity, Ganoderma, oil palm, smallholder plantations}

\section{INTRODUCTION}

Basal Stem Rot disease is a significant disease that is still difficult to control in oil palm plantations, especially in Indonesia. This disease is caused by the pathogenic fungus Ganoderma boninense which has caused significant economic losses in the palm oil industry (Kresnawaty, at al., 2017; Yuliar and Suciatmih, 2018), because it can cause death by up to $50 \%$ resulting in a decrease in oil palm production [1].

Ganoderma spp. It is an important pathogen to control because it can attack oil palm plants from the nursery level to the field known as Basal Stem Rot (BSR) disease. Basal Stem Rot disease could kill more than $80 \%$ of oil palm trees that have half their economic life span [2]. Ganoderma sp. can also cause Upper Stem Rot symptoms, which are predominantly found on peatlands in Labuhan Batu, North Sumatra [3]. Previously Susanto et al. have reported that the incidence of scion rot reached more than $35 \%$ in Tanjung Selamat [3].
Turner has reported that there are 15 species of Ganoderma from various regions of the world that are associated with stem rot disease in oil palm plants. Some of them are G. boninense, G. zonatum, G. miniatocinctum, G. tornatum, G. applanatum, G. chalceum, G. lucidium and G. pseudoferreum [4]. In a recent study in Malaysia, it was found that the species G. tornatum is a non-pathogenic species that only attacks the stems of dead oil palms [5].

In Indonesia, other types of information related to Ganoderma spp. which attacks oil palm plantations have not been widely reported. Information regarding the genetic diversity of Ganoderma needs to be known, considering that each pathogen has specificity in causing disease. This information is necessary to determine how the mechanism of infection, spread, and the response of plants to the presence of each type of Ganoderma in the physiological processes of oil palm plants. 


\section{MATERIALS AND METHODS}

This research was conducted using survey methods in smallholder oil palm plantations in Kampar Regency and the Plant Disease Laboratory, Faculty of Agriculture, Riau University. The sampling location was determined using purposive random sampling with the criteria of smallholder oil palm plantations showing symptoms of basal stem rot disease. Ganoderma spp. taken from the infected oil palm plant in the form of a basidioma that has appeared at the base of the oil palm trunk. Basidioma of Ganoderma spp. obtained from the field then characterized based on its color. The data from these observations were then analyzed descriptively and presented in the form of tables and pictures.

\section{RESULTS AND DISCUSSION}

\subsection{Morphology and Disease Severity in oil palm plants infected with Ganoderma spp.}

Ganoderma basidioma samples were obtained from Deli Makmur Village, Kampa District. This village was chosen because it has a high Ganoderma attack. Based on the data obtained, the age of oil palm plants has been more than 17 years which is managed by the community. Oil palm is planted on peatland. In general, the plant samples were infected by Ganoderma sp. with different conditions which can be seen in Table 1 .

Based on the results of the survey conducted, from the Deli Makmur villages that have been determined, it was found that there was an attack by Ganoderma sp. accompanied by the formation of a basidioma. The details of the condition of the oil palm plantations in Deli Makmur village are detailed in Table 1.

Data in Table 1 shows that there are several variations of the attack symptoms of Ganoderma sp. According to Pilotti, oil palm plants that are attacked by stem rot disease in the field can be seen from the crown of the plant with the formation of more leaves than usual. Besides, the leaves are pale green, the old leaves wilt, break off the midrib, and hang around the tree. A typical symptom is the occurrence of rot at the base of the stem followed by the appearance of a mushroom basidioma [6].

Symptoms of attack and the presence of Ganoderma sp. in oil palm plantations vary widely. From the data in Table 4.1, the severity of the disease seen from the condition of the plants attacked by Ganoderma and the disease rating scale is not always determined by the number of fronds and spear leaves, but by the presence of the basidioma of Ganoderma sp.

Based on symptom observation results in Table 2 showed that $62.07 \%$ of severe symptoms, $10.34 \%$ dead plants, $20 \%$ had moderate symptoms and only $6.90 \%$ had mild symptoms. In general, the condition of the plants in the study location showed severe symptoms, with a disease severity index reaching $75 \%$. This shows that the incidence of Ganoderma in smallholder oil palm plantations is very high. This can be caused by a lack of care and disease control techniques practiced by farmers in community gardens. Besides, the use of uncertified oil palm seeds is also an obstacle to the vulnerability of oil palm to being attacked by Ganoderma sp. [7].
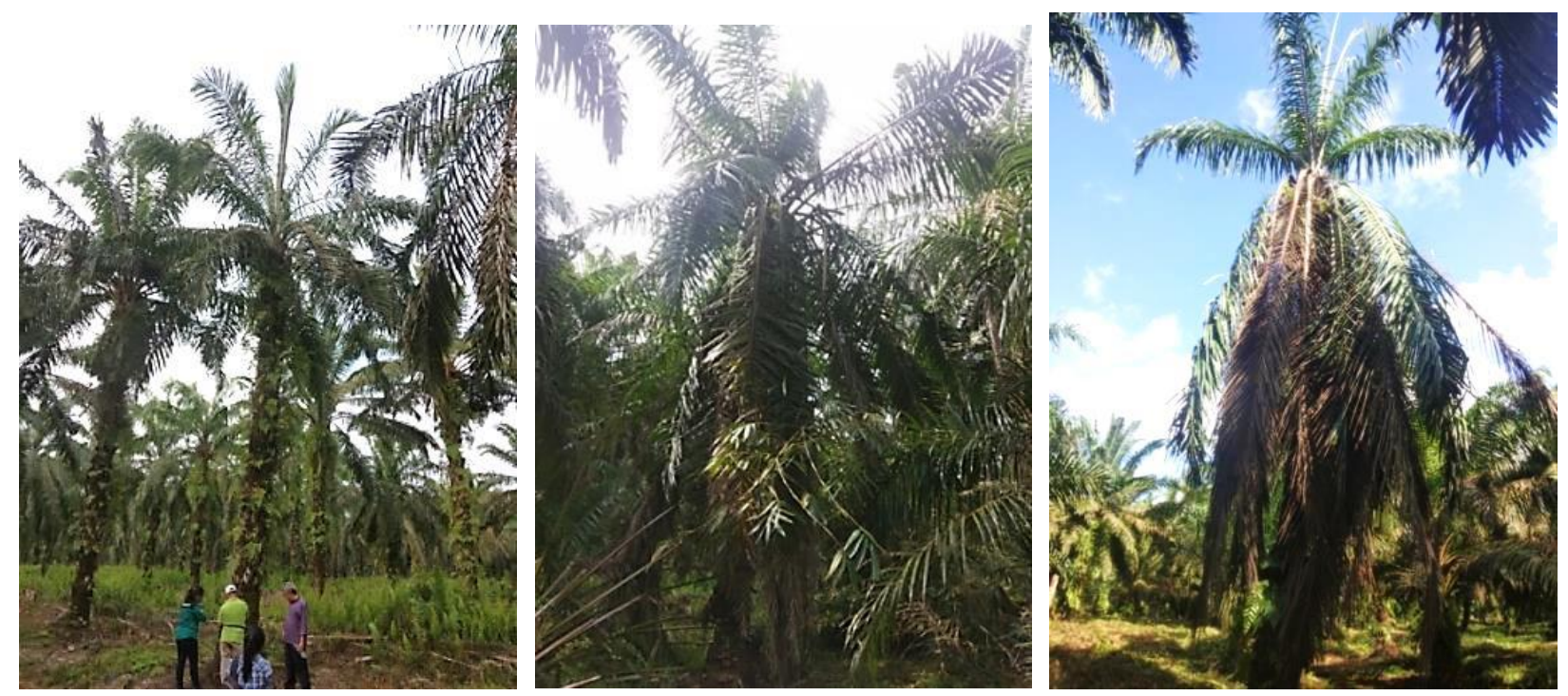

Figure 1 Morphology of diseased plants infected by Ganoderma spp. with mild (a), moderate (b) and severe conditions Deli Makmur Village, Kampa District, Kampar Regency. 
Table 1. Description of the condition of the oil palm trees attacked by Ganoderma sp.

\begin{tabular}{|c|c|c|c|c|c|c|}
\hline \multirow[b]{2}{*}{ Sample Location } & \multirow[b]{2}{*}{$\begin{array}{l}\text { Sample } \\
\text { Code }\end{array}$} & \multicolumn{3}{|c|}{ Plant Infected Symptoms by Ganoderma sp. } & \multirow[b]{2}{*}{$\begin{array}{l}\text { Condition of } \\
\text { plant severity }\end{array}$} & \multirow[b]{2}{*}{$\begin{array}{c}\text { Disease } \\
\text { Rating } \\
\text { Scale }\end{array}$} \\
\hline & & $\begin{array}{c}\text { Number of } \\
\text { Spear } \\
\text { Leaves }\end{array}$ & $\begin{array}{c}\text { Number of } \\
\text { Hanging Fronds }\end{array}$ & $\begin{array}{c}\text { Number } \\
\text { of } \\
\text { Basidioma }\end{array}$ & & \\
\hline \multirow{14}{*}{$\begin{array}{l}\text { Deli Makmur, } \\
\text { Dahlia Sari } \\
\text { Village (DMDS) }\end{array}$} & DMDS01 & 0 & 0 & 6 & Dead Plants & 5 \\
\hline & DMDS02 & 0 & 0 & 5 & Dead Plants & 5 \\
\hline & DMDS03 & 3 & 15 & 5 & Heavy & 4 \\
\hline & DMDS04 & 3 & 13 & 4 & Heavy & 4 \\
\hline & DMDS05 & 1 & 2 & 5 & Heavy & 4 \\
\hline & DMDS06 & 2 & 1 & 1 & Mild & 2 \\
\hline & DMDS07 & 3 & 10 & 2 & Heavy & 4 \\
\hline & DMDS08 & 4 & 16 & 5 & Heavy & 4 \\
\hline & DMDS09 & 2 & 9 & 5 & Moderate & 3 \\
\hline & DMDS10 & 3 & 11 & 3 & Heavy & 4 \\
\hline & DMDS11 & 2 & 11 & 3 & Heavy & 4 \\
\hline & DMDS12 & 4 & 15 & 4 & Heavy & 4 \\
\hline & DMDS13 & 5 & 12 & 4 & Heavy & 4 \\
\hline & DMDS14 & 3 & 21 & 6 & Heavy & 4 \\
\hline \multirow{12}{*}{$\begin{array}{l}\text { Deli Makmur, } \\
\text { Dahlia Makmur } \\
\text { Village (DMDM) }\end{array}$} & DMDM01 & 3 & 7 & 3 & Moderate & 3 \\
\hline & DMDM02 & 2 & 5 & 5 & Heavy & 4 \\
\hline & DMDM03 & 3 & 11 & 5 & Heavy & 4 \\
\hline & DMDM04 & 2 & 2 & 4 & Moderate & 3 \\
\hline & DMDM05 & 3 & 2 & 5 & Heavy & 4 \\
\hline & DMDM06 & 4 & 2 & 7 & Heavy & 4 \\
\hline & DMDM07 & 2 & 0 & 1 & Mild & 2 \\
\hline & DMDM08 & 3 & 5 & 2 & Moderate & 3 \\
\hline & DMDM09 & 2 & 1 & 3 & Moderate & 3 \\
\hline & DMDM10 & 4 & 7 & 2 & Heavy & 4 \\
\hline & DMDM11 & 2 & 3 & 3 & Moderate & 3 \\
\hline & DMDM12 & 3 & 7 & 2 & Heavy & 4 \\
\hline
\end{tabular}

\subsection{Diversity of Ganoderma spp. Basidioma Morphology from Smallholder Palm Oil Plantation}

Data from field observations, based on the morphology of Ganoderma basidioma found at the base of the oil palm plant stem, show that there are several variations. In this observation, variations in the diameter of the basidioma were not used as a differentiating parameter, due to different development stages and land conditions. This is based on the opinion of Ryvarden (1955) in Bhosle et al., which states that the shape and size of the basidiocarp (basidioma) are doubtful in terms of morphological characteristics [8]. In this study, the diversity of Ganoderma $\mathrm{sp}$. is seen from the color of the basidioma obtained. In general, based on field data, it was found that there were six groups of basidioma colors of Ganoderma sp. namely the Gano-1 group, Gano-2 group, Gano-3 group, Gano-4 group, Gano-5 group and Gano-6 group (Figure 2).

The basidioma characteristics in the Gano-1 group show wavy pilleus (surface), shiny light brown to dark color, white areas on the edges of the pilleus and the basidioma is not too thick. The basidioma morphology in the Gano-2 group showed wavy pilleus, shiny yellowish brown with white areas on the edges of the pilleus and the basidioma was not too thick. The Gano-3 group showed characteristic basidioma with flat, brown, matte pilleus with white patches on the pilleus and thin basidioma.

The basidioma morphology of Gano-4 group shows wavy pilleus, shiny reddish to dark brown with basidioma not too thick. The Gano-5 group showed a characteristic light brown wavy pilleus, and the basidioma was not too thick. The characteristics of the Gano- 6 group are different from other groups, namely wavy pilleus, purplish brown with thick basidioma. In general, the presence of basidioma in the six groups was different in each location and sample plants as shown in Table 2.

The data in Table 2 also shows the highest incidence of Ganoderma sp. those in the field were the Gano-1 group $(79.31 \%)$ and the Gano-4 group $(31.03 \%)$. The other four groups were found to be small in numbers at the study site. 
Table 2 Description of the morphological diversity of the basidioma of Ganoderma sp. from the affected oil palm plant

\begin{tabular}{|c|c|}
\hline Ganoderma spp. Group & $\begin{array}{c}\text { Ganoderma sp. group } \\
\text { Incident }\end{array}$ \\
\hline Gano-1 Group & $79.31 \%$ \\
\hline Gano-2 Group & $17.24 \%$ \\
\hline Gano-3 Group & $10.34 \%$ \\
\hline Gano-4 Group & $31.03 \%$ \\
\hline Gano-5 Group & $13.79 \%$ \\
\hline Gano-6 Group & $6.90 \%$ \\
\hline
\end{tabular}
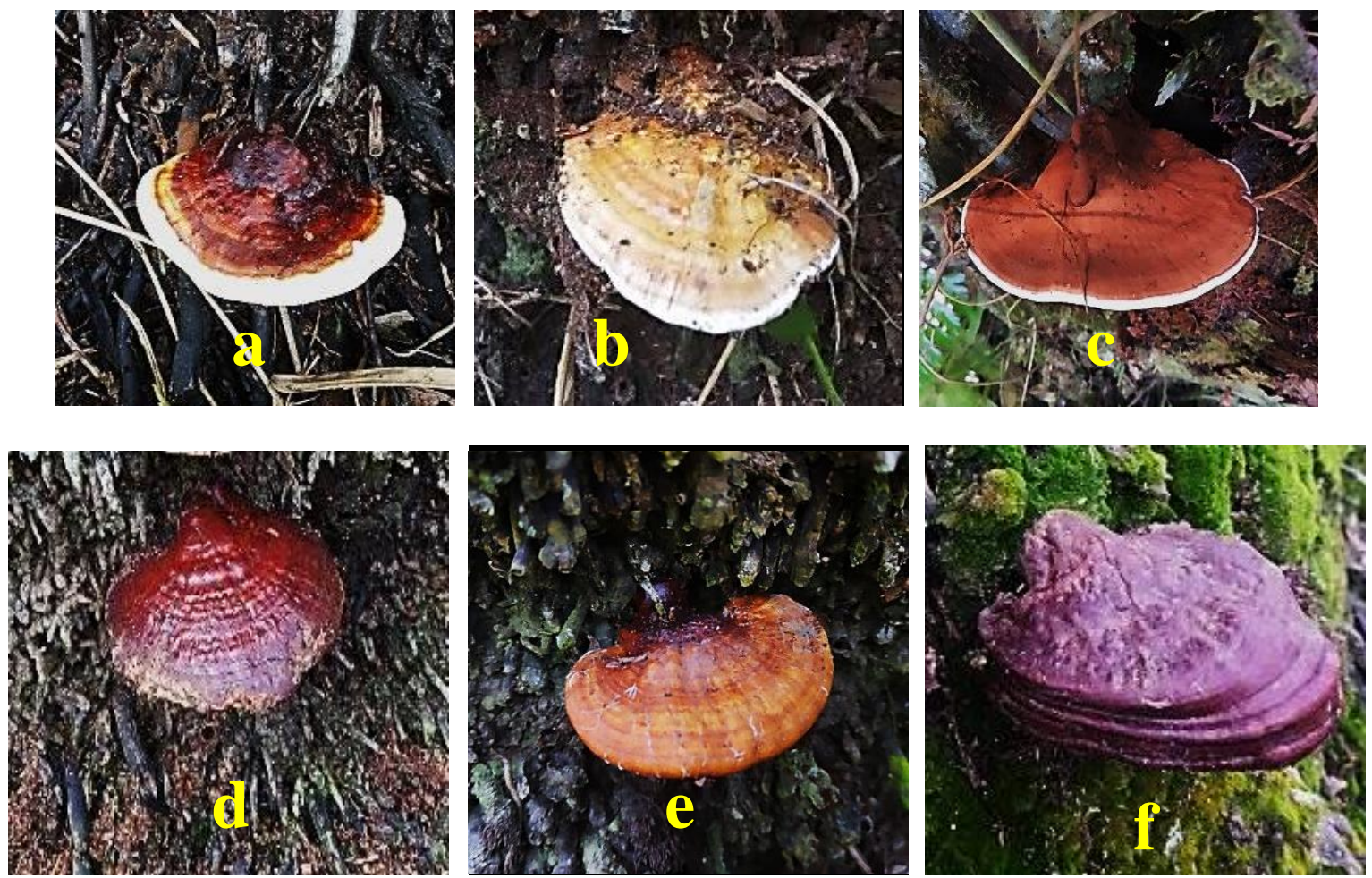

Figure 2 The color diversity of Ganoderma sp. a) Gano-1 Group, b) Gano-2 Group, c) Gano-3 Group, d) Gano-4 Group, e) Gano-5 Group dan f) Gano-6 Group

The results of observations in the field also found a double incidence, namely several types of Ganoderma sp. Based on the diversity of colors in one plant. There were also several types of Ganoderma in one plant. The data in Figure 3 shows that there is a $38 \%$ incidence of 2 groups of Ganoderma in one plant, $10 \%$ when 3 types of Ganoderma are found in one plant and $52 \%$ a single incidence.
Based on the color of the basidioma in the Gano-1 group, it is suspected that this is Ganoderma boninese Pat. This is consistent with the description by Markom et.al. statement that $G$. boninense is the main fungal pathogen that causes the stem rot disease in oil palm plants [9]. It is necessary to carry out further tests using molecular characteristics to determine the diversity of these 6 Ganoderma groups. 


\section{CONCLUSION}

The plant condition in Deli Makmur Village shows severe symptoms with a severity index reaching $75 \%$. There were 6 groups of Ganoderma based on the characteristic color variations of the basidioma found in the sample locations. The Gano-1 group is the group with the highest incidence found in the field. This study also found $48 \%$ of infections of more than 1 Ganoderma group in one oil palm plant. Further testing is needed to determine the diversity of this Ganoderma species based on its genetic characteristics.

\section{ACKNOWLEDGMENT}

This work was supported by Lembaga Penelitian dan Pengabdian Kepada Masyarakat (LPPM) Universitas Riau from DIPA with contract number 746 /UN.19.5.1.3/PT.01.03/2020.

\section{REFERENCES}

[1] T.W. Darmono, 'Ganoderma in oil palm Indonesia: Current Status and Prospective Use Antibodies for Detection of Infection. In. Herman,G.E. \& C.P. Kubice. (Eds) Trichoderma and Gliocladium Volume 1: Enzymes, biological control and commercial applications', Taylor \& Francis Ltd. UK, 1998.

[2] A.S. Idris, M. Yamaoka, S. Hayakawa, M.W. Basri, I. Noorhasimah, D. Ariffin, PCR Technique for
Detection of Ganoderma. MPOB Information Series, vol. 188, no. 4, 2003.

[3] A. Susanto, A.E. Prasetyo, H. Priwiratama, S. Wening, Surianto, Ganoderma boninense as Causal Agent of Upper Stem Rot Disease of Oil Palm, Jurnal Fitopatologi Indonesia, vol. 9, no. 4, pp. 123-126, 2013. DOI: 10.14692/jfi.9.4.123.

[4] P.D. Turner, 'Oil Palm Diseases and Disorders', Oxford University Press, US. 1981.

[5] L. Wong, C.J. Bong and A.S. Idris, Ganoderma spesies Associated with Basal Stem Rot Disease of Oil Palm. Am. J. Applied Sci., vol. 9, no. 6, pp. 879885, 2012.

[6] C.A. Pilotti, Stem Rots Of Oil Palm Caused By Ganoderma boninense: Pathogen Biology and Epidemiology, Mycopathologia, vol. 159, pp. 129137, 2005.

[7] L. Siswati, R. Harly, Afrijon. Manajemen Produksi dan Pemeliharaan Kebun Kelapa Sawit Rakyat, Jurnal Agribisnis, vol. 19, no. 2, pp. 95-101, 2017.

[8] S. Bhosle, K. Ranadive, G. Bapat, S. Garad, G. Deshpande, J. Vaidya, Taxonomy and Diversity of Ganoderma from the Western parts of Maharashtra (India). Mycosphere, vol. 1, no. 3, pp. 249, 2010.

[9] M.A. Markom, A.Y. Md Shakaff, A.H. Adom, M.N. Ahmad, W. Hidayat, A.H. Abdullah, N. A. Fikri, Intelligent electronic nose system for basal stem rot disease detection, Computers and Electronics in Agriculture, vol. 66, pp. 140-146, 2009, doi:10.1016/j.compag.2009.01.006. 